\title{
Prognostic significance of DNMT3a gene expression and reactive nitrogen species in newly diagnosed Egyptian de novo adult acute myeloid leukemia patients
}

Inas A. Asfour', Hany M. Hegab', Walaa A. El-Salakawy', Mohamed T. Hamza², Dina A. Mansour ${ }^{1}$ and Alia M. Saeed ${ }^{1 *}$ (D)

\begin{abstract}
Background: DNA methyltransferase 3a (DNMT3a) gene is a frequently dysregulated epigenetic modifier gene involved in the process of carcinogenesis. Also, there is a dichotomous nature of nitric oxide action with the ability to both promote and repress cancers. There is a host of research work delineating the frequency of DNMT3a mutation in acute myeloid leukemia (AML), but little is known about its level of expression in AML patients or its probable relationship to nitrosative stress. This study aims at the assessment DNMT3a gene expression as well as nitric oxide levels in newly diagnosed adult patients with de novo AML. Moreover, it aims at relating these two variables to other disease features and prognostic indicators as well as treatment outcomes. The study included 45 adult de novo AML patients and 10 healthy control subjects. Measurement of DNMT3a messenger ribonucleic acid (mRNA) transcripts was done by real-time quantitative polymerase chain reaction (RQ-PCR) followed by Sanger sequencing to identify the presence or absence of DNMT3a arginine 882 (R882) mutation. This was followed by the assessment of serum nitrite level as a surrogate marker for nitric oxide radical (NO) using colorimetric methods.
\end{abstract}

Results: DNMT3a gene expression, as well as serum nitrite levels, were significantly higher among AML cases in relation to controls before chemotherapy with $P$ values of $<0.001$ and 0.035 , respectively. Dividing patients into low and high expressors in relation to the hotspot mutation demonstrated no difference between the two groups in terms of demographic, clinical, and laboratory characteristics or treatment outcomes.

Conclusion: DNMT3a gene expression is increased among the AML population in relation to normal healthy controls. This may point out the need for the assessment of the influence of this gene expression on methylcytosine content of tumor samples with the subsequent implementation of hypomethylating agents as a line of therapy in cases exhibiting excessive hypermethylation.

Keywords: AML, APL, DNMT3a, RNS, NO

\footnotetext{
* Correspondence: Aliasaeed81@med.asu.edu.eg

'Department of Internal Medicine, Clinical Hematology and Oncology Unit,

Faculty of Medicine, Ain Shams University, Cairo, Egypt

Full list of author information is available at the end of the article
}

\section{Springer Open}

(- The Author(s). 2020 Open Access This article is licensed under a Creative Commons Attribution 4.0 International License, which permits use, sharing, adaptation, distribution and reproduction in any medium or format, as long as you give appropriate credit to the original author(s) and the source, provide a link to the Creative Commons licence, and indicate if changes were made. The images or other third party material in this article are included in the article's Creative Commons licence, unless indicated otherwise in a credit line to the material. If material is not included in the article's Creative Commons licence and your intended use is not permitted by statutory regulation or exceeds the permitted use, you will need to obtain permission directly from the copyright holder. To view a copy of this licence, visit http://creativecommons.org/licenses/by/4.0/. 


\section{Background}

Acute myeloid leukemia (AML) is a disease with marked molecular as well as clinical diversity [1]. DNA methylation and histone tail modifications are the two fundamental epigenetic regulatory mechanisms modulating gene expression. They play a critical role in hematopoietic cellular differentiation with a contribution to leukemogenesis when dysregulated [2].

The process of DNA methylation is catalyzed by a set of enzymes called DNA methyltransferases (DNMTs) [3]. DNA methyltransferase 3a (DNMT3a) is an enzyme that catalyzes the addition of a methyl group to 5 cytosine residue of 5'Cytosine-phosphate-guanine3' (CpG) dinucleotides. This recruits methyl-binding proteins and other repressor complexes precluding the access of transcription factors to the gene with the subsequent gene silencing [4].

$D N M T 3 a$ is one of the frequently mutated genes in myeloid malignancies such as acute myeloid leukemia, myelodysplasia, and myeloproliferative neoplasms [5]. The most common mutation of DNMT3a is the alteration of arginine 882 (R882) affecting the canonical methyltransferase domain with a substantial reduction of the enzymatic activity causing focal areas of DNA hypomethylation [6]. There is a controversy regarding the influence of this mutation on the clinical outcome in AML patients [7].

Reactive nitrogen species (RNS) is a collective term that includes nitric oxide (NO), peroxynitrite (ONOO-), nitrogen dioxide radical (NO2). NO is an essential molecule playing a role in cell signaling, immune responses as well as vasodilatation [8]. The role of nitric oxide in tumorigenesis is controversial with bimodal action. Some reports contend that it has a tumor promoting properties, whereas others claim that it has tumoricidal activity [9].

\section{Methods}

\section{Subjects}

This prospective case-control study was conducted in the Clinical Hematology and Oncology Unit, Internal Medicine Department at Center "X", City "Y", Country "Z". A total number of 55 adult subjects were enrolled. Participants of the study were divided into 2 groups.

Patient group (group 1): was made up of 45 patients of newly diagnosed de novo AML, who met the criteria of selection.

\section{Inclusion criteria}

- Adult patients of 18 years old or more.

- Newly diagnosed AML patients by the standard diagnostic criteria.

- Patients who were deemed fit for chemotherapy.

\section{Exclusion criteria}

- Secondary acute leukemia.

- Biphenotypic or bileaneage acute leukemia.

- Relapsed acute leukemia.

- Patients who were considered unfit to intensive chemotherapy of curative intent.

Control group (group 2): consisted of 10 healthy control subjects who were both age- and sex-matched.

\section{Plan of treatment}

All patients received chemotherapy protocols in accordance with the National Comprehensive Cancer Network (NCCN) guidelines 2016 [10]. Non-APL cases received standard $3+7$ protocol [11]. APL cases were induced by PETHEMA protocol described elsewhere [12].

Non-APL cases received high-dose cytarabine (HiDAC) as consolidation chemotherapy every 28 days after the achievement of complete remission (CR) by the end of induction [13]. Good risk cases and cases having no matched sibling donor (MSD) received 4 cycles of HiDAC, whereas intermediate and poor-risk cases having MSD were allo-transplanted. Till their access to the transplantation facility, they were given HiDAC cycles with a maximum of 4 cycles.

\section{Assessment of response}

Recommendations published by the international working group in 2003 were used to standardize response criteria. Patients were classified into either responders who attained CR or refractory who failed to achieve CR. CR was defined as an absolute neutrophilic count $\geq 1,000$ / ul, platelet count $\geq 100,000 /$ microliter (ul), and $<5 \%$ bone marrow blasts with no evidence of extramedullary disease. However; refractory disease was defined by patient surviving $\geq 7$ days following the completion of the initial treatment course with persistent leukemia in the last peripheral blood smear and/or bone marrow, or with the persistent extramedullary disease [14].

\section{Sample collection}

For each subject, about $5 \mathrm{ml}$ of venous blood was drawn under complete aseptic conditions and dispensed into a labeled vacutainer containing gel and clot activator, and serum was separated by centrifugation for $5 \mathrm{~min}$, then stored at $-20^{\circ} \mathrm{C}$ till the assay for the measurement of DNMT3a expression as well as mutational status and NO levels. This was repeated after 1 month of induction therapy.

Detection of DNMT3a gene expression and mutation Measurement of DNMT3a gene expression by RQ-PCR Using RQ-PCR, both groups were subjected to the measurement of DNMT3a mRNA transcripts and their 
comparison to the expression of a reference housekeeping gene. For AML cohort, expression was assayed twice, once before induction chemotherapy and another after the end of induction. For that purpose, RNA was extracted from fresh peripheral blood samples with QIAamp RNA blood mini kit (Qiagen, Germany) according to the manufacturer's spin protocol. RNA quantification was done using Nanodrop at A230/A260 nanometer $(\mathrm{nm})$ wavelength. High-Capacity DNA Reverse Transcription Kit (Applied Biosystems, USA) is designed for reverse transcription of RNA amounts greater than 20 nanogram per microliter ( $\mathrm{ng} / \mathrm{ul})$. Reverse transcription reactions were performed using the High-Capacity complementary DNA (cDNA) Reverse Transcription Kit (Applied Biosystems, USA) in a final volume of $20 \mu \mathrm{l}(10 \mu \mathrm{l}$ $2 \times \mathrm{RT}$ master mix $+10 \mu \mathrm{l}$ RNA sample). Thermal cycler program utilized as follows: incubation was done for $30 \mathrm{~min}$ at $25^{\circ} \mathrm{C}, 120 \mathrm{~min}$ at $37^{\circ} \mathrm{C}, 5 \mathrm{~min}$ at $85^{\circ} \mathrm{C}$ then maintained at $4{ }^{\circ} \mathrm{C}$. For real-time PCR, $2 \mu \mathrm{l}$ of cDNA products were mixed with $10 \mu \mathrm{l}$ of Taqman PCR master mixture (No UNG), $1 \mu \mathrm{l}$ of Taqman gene expression assay and $7 \mu \mathrm{l}$ of nuclease-free water in a final volume of $20 \mu \mathrm{l}$. All reactions were performed on a StepOne Real-Time PCR System (Applied Biosystems, USA) with the following conditions: $95^{\circ} \mathrm{C}$ for 10 min, followed by 40 cycles at $95^{\circ} \mathrm{C}$ for $15 \mathrm{~s}$, and $60^{\circ} \mathrm{C}$ for 1 min. Taqman gene expression assay for DNMT3a target gene was supplied ready to use by ThermoFisher Scientific (Cat no. 4351372). Relative quantitation was performed using ACTB TaqMan Gene Expression Assays for beta-actin reference gene $(A C T B)$ supplied ready to use by ThermoFisher Scientific (Cat no. 4448892). As RQ-PCR requires the simultaneous detection of different fluorescent reporter dyes whose fluorescence spectra exhibit minimal spectral overlap, the two reporter dye labels used were FAM $^{\text {ma }}$ (for DNMT3a target gene) and VIC (for ACTB gene). Both QuantiFast Probe Assays were labeled with a non-fluorescent quencher. Results were reported in relative quantification. Relative quantification was based on the expression levels of the target gene versus the reference one. To calculate the expression of the target gene in relation to the adequate reference gene, calculations were done based on the comparison of a distinct cycle in realtime PCR determined by cycle threshold (CT) values of thermal cyclers at a constant level of fluorescence [15]. After determining the $C T$, the $\triangle C T$ value for each sample was determined by calculating the difference between the CT value of the target gene and the CT value of the endogenous reference gene. This was determined for each unknown sample as well as for the calibrator sample (control subjects).

\section{Assessment of DNMT3a mutations by Sanger sequencing}

SigmaSpin ${ }^{\text {Tx }}$ Post-Reaction clean-up kit (Sigma-Aldrich, S5059) was used to clean up the PCR reactions. The sequencing reaction was set up using BigDye ${ }^{\bullet}$ Terminator v1.1 Cycle sequencing kit (Applied Biosystems, 4336774). A typical sequencing reaction consisted of $1 \mu \mathrm{L}$ of cleaned Product, $4 \mu \mathrm{L}$ of $2.5 \times$ ready reaction mix, $4 \mu \mathrm{L}$ of $5 \times$ BigDye Sequencing Buffer, $0.5 \mu \mathrm{M}$ of forward and reverse primers respectively in different tubes. The sequencing reactions were then run on ABI PRISM 310 Genetic Analyzer (POP6). The sequences were based, called, and analyzed using sequence analysis software SeqScape V 2.7 which is designed to detect mutations when aligned with reference sequences of the particular gene.

Primer sequences used for the analysis of DNMT3a mutations [16]

Forward: TGTGTGGTTAGACGGCTTCC

Reverse: CCCCCATGTCCCTTACACAC

Amplicon size (bp): $229+$ tag

\section{Detection of nitric oxide (NO)}

At diagnosis, the measurement of $\mathrm{C}$-reactive protein (CRP) was done to all the study participants as an index for the presence of infection. This was done to discriminate the elevation of $\mathrm{NO}$ secondary to infection from that which was related to the disease process. The assessment of $\mathrm{NO}$ level was impossible due to its very short half-life (only 15 s), and hence, serum nitrite was used as a surrogate marker. It was assayed in the serum of patients twice at diagnosis and on day 28, whereas it was assayed once in controls as seen in Table 1. The Biodiagnostic Nitrite Assay Kit number 2533, for nitric oxide assay, provides an accurate and convenient method for the measurement of endogenous nitrite concentration. The assessment of nitrite depends upon adding Griess reagent which converts nitrite into the deep purple azo compound, this is followed by photometric measurement of the absorbance resulting from this azo chromophore which accurately determines $\mathrm{NO}$ concentration. Blood sample centrifuged and stored at $-200{ }^{\circ} \mathrm{C}$ to $-800^{\circ} \mathrm{C}$. Prior to this, the sample was perfused with phosphate-buffered saline solution, then centrifuged at 4000 round per minute $(\mathrm{rpm})$ for $15 \mathrm{~min}$ at $40^{\circ} \mathrm{C}$. Finally, the supernatant was removed and stored on ice as the assay was not conducted on the same day. The effect of media components on color development was assessed by making a nitrite standard curve in the presence of a fixed volume of blood sample and comparing it to a nitrite standard curve made in buffer alone. Results expected were as the following: if antioxidants were present in the blood, they would interfere with the color development when at a concentration as low as 100 micromole $(\mu \mathrm{M})$, when using the maximum amount of sample for the nitrite assay $(100 \mu \mathrm{l})$, the detection limit is $2.5 \mu \mathrm{M}$. With using reagents as follows: standard sodium nitrite $(50$ micromole/liter $(\mu \mathrm{mol} / \mathrm{l}))$, sulphanilamide $(10$ millimole/liter $(\mathrm{mmol} / \mathrm{l}))$, and $N-(1$ naphthyl) ethylenediamine (NEDA) $(1 \mathrm{mmol} / \mathrm{l})$ test was 
Table 1 Demographic data and patient characteristics

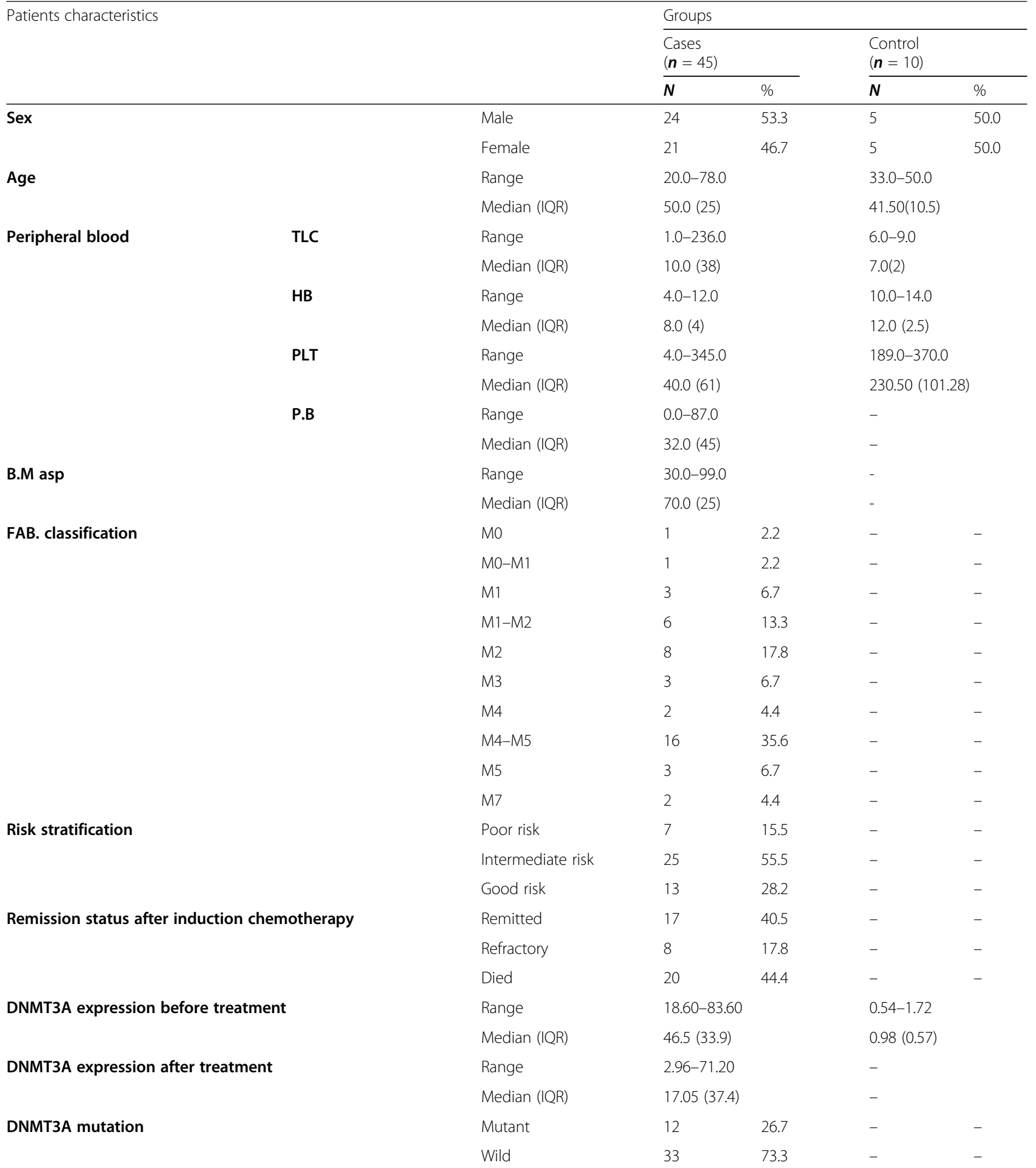


Table 1 Demographic data and patient characteristics (Continued)

\begin{tabular}{|c|c|c|c|c|c|}
\hline \multirow[t]{3}{*}{ Patients characteristics } & & \multicolumn{4}{|c|}{ Groups } \\
\hline & & \multicolumn{2}{|c|}{$\begin{array}{l}\text { Cases } \\
(\boldsymbol{n}=45)\end{array}$} & \multicolumn{2}{|c|}{$\begin{array}{l}\text { Control } \\
(\boldsymbol{n}=10) \\
\end{array}$} \\
\hline & & $N$ & $\%$ & $N$ & $\%$ \\
\hline \multirow[t]{2}{*}{ DNMT3A expression } & Low expression & 22 & 48.9 & 10 & 100.0 \\
\hline & High expression & 23 & 51.1 & 0 & 0.0 \\
\hline \multirow[t]{2}{*}{ NO level pre-treatment } & Range & \multicolumn{2}{|c|}{$0.53-60.90$} & \multicolumn{2}{|c|}{$0.0-22.11$} \\
\hline & Median (IQR) & \multicolumn{2}{|c|}{$12.0(16.78)$} & \multicolumn{2}{|c|}{$5.80(9.65)$} \\
\hline \multirow[t]{2}{*}{ NO level post-treatment } & Range & \multicolumn{2}{|c|}{$0.0-27.50$} & \multicolumn{2}{|l|}{-} \\
\hline & Median (IQR) & \multicolumn{2}{|c|}{$6.20(8.8)$} & \multicolumn{2}{|l|}{ - } \\
\hline
\end{tabular}

$H g B$ hemoglobin, NO nitric oxide, $P B$ peripheral blood blast, $P L T$ platelets, $T L C$ total leucocytic count NB: the empty cells are for the unapplied points of comparison for the control grou

done by mixing the blood sample with reagent well, allowing it to stand for $5 \mathrm{~min}$, then the absorbance of the sample examined was read against the absorbance of the standard blank sample at $540 \mathrm{~nm}(520-550 \mathrm{~nm})$. The color was found to be stable for many hours with linearity up to $200 \mu \mathrm{mol} / \mathrm{l}$.

Nitrite in the sample was calculated as follows:

Nitrite in micromoles $(\mathrm{Umol} / \mathrm{L})=$ examined sample/ standard sample $\times 50$

\section{Statistical methodology}

Data were analyzed using IBM SPSS software package version 20.0. (Armonk, NY: IBM Corp). The Kolmogorov-Smirnov test was used to verify the normality of distribution. Qualitative data were described as frequencies and percentages, whilst quantitative data were described using range (minimum and maximum), mean, standard deviation when they are parametric and median and interquartile range when they are non-parametric. The significance of the obtained results was judged at the $5 \%$ level.

\section{Results}

A total number of 55 adult subjects were enrolled. Participants were divided into 2 groups; the first group constitutes 45 patients of adult newly diagnosed de novo AML and the second one made of 10 adult healthy matched controls as per age and sex. Table 1 illustrates the demographic, clinical, and laboratory data of the whole cohort. AML group consisted of 24 males (53.3\%) and 21 females (46.7\%) whilst the control group included 5 males and 5 females. Age of AML patients ranged from 20 to 78 years with a median of 50 years whereas the control group age ranged from 33 to 50 years with a median of 41.5 years.

Bone marrow aspirates were done at diagnosis exhibiting a median blast percentage of $70 \%$. Immunophenotyping segregated cases as per the French-AmericanBritish (FAB) classification. Twenty-one patients had
M4-M5 phenotype, eight patients belonged to M2 category making up $17.8 \%$ of the entire cohort. APL contributed by $6.7 \%$ of cases, i.e., 3 cases. AML (M4) and (M7) had comparable presentations of about $4.4 \%$, whilst AML (M0) and AML (M0-M1) had the least contributions with $2.2 \%$ for each. Cytogenetic-based risk stratification of the study group was performed in congruence with the NCCN guidelines 2016 [11], twenty-five patients fitted into the intermediate-risk group constituting $55 \%$ of the cohort. Of them, 21 patients exhibited normal karyotype (i.e., cytogenetically normal AML (CNAML)). The remaining 4 patients were divided into two cases with trisomy 8 , one case with trisomy 6 , and another case with monosomy $\mathrm{X}$. The good risk was evident in 13 patients accounting for $28.9 \%$ of the cohort. Two patients of this group were belonging to APL with its hallmark cytogenetic abnormality $t(15: 17)$. Four patients had $t(8: 21)$ and 7 patients had inv(16) affecting the alpha and beta subunits of core-binding factor $(\mathrm{CBF})$, respectively. Poor risk made the lowest contribution to the cohort making $15.5 \%$ (i.e., 7 cases). Four of them had complex karyotype with monosomal karyotype encountered in one of them. This patient had a karyotype of 40, $\mathrm{XY}$ with loss of chromosomes 2, 3, 7, 14, and 18. Two patients had monosomy 7 and 1 had deletion 5q. This information is well-delineated in Table 1.

\section{Treatment outcome}

Patients' cohort was followed up for 18 months from the start of the enrollment into the study, it was found that the median survival was 37 days. A total of $44.4 \%$ of cases enrolled died during the induction; of them, $95 \%$ died out of infectious complications. When dealing with the patients who survived after the induction, they were 25 cases $(55.5 \%)$ divided into three subgroups; complete responders, partial responders, and refractory. Patients who achieved CR $(n=13)$ were offered their consolidation in accordance with the cytogenetic risk category and the availability of an MSD. Out of our cohort, we 
had 2 patients who were eligible for transplantation, the first patient was admitted in center " $X$ " Bone Marrow Transplantation Unit to undergo the procedure; however, the other one died out of infection before accessing the transplant facility. By contrast, the patients who were not candidates for transplantation-either being good risk or lacking a potential donor-completed 4 cycles of HiDAC. Six patients out of the remaining eleven patients did not complete their 4 cycles due to the following reasons: four of them died out of infectious sequelae and the other two had disease recurrence and were deemed refractory. Four patients attained partial remission (PR) and hence they were re-induced with the same induction protocol. Eight patients did not achieve either PR or CR post-induction chemotherapy and were considered chemo-resistant. These patients were submitted to salvage chemotherapy.

\section{DNMT3a expression}

Upon the evaluation of DNMT3a expression among cases and controls, it was found that the median expression for AML group pre-chemotherapy was 46.5 with a range from 18.6 to 83.6 and IQR of 33.9. At the end of treatment, re-measurement of mRNA transcript levels yielded an evident decrease of the expression showing a median of 17 ranging from 2.9 to 71.2 with IQR of 37.4 . This is in contrast to control group that showed markedly lower values in comparison to AML group in either time-points with a median of 0.98 ranging from 0.54 to 1.72 with IQR of 0.52 . As shown in Fig. 1, when
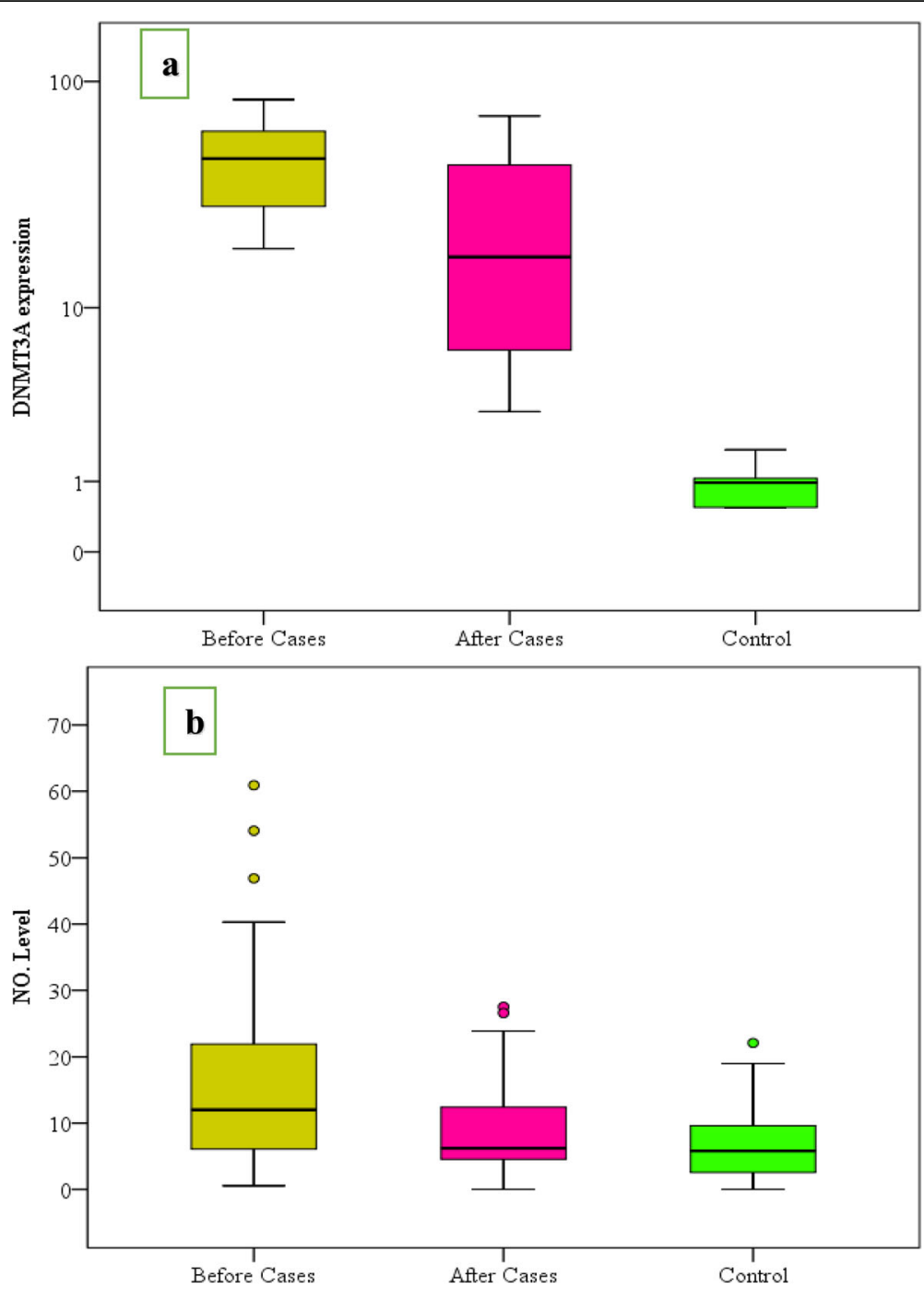

Fig. 1 a Comparison between mutated, un-mutated, and control groups as per DNMT3a expression before and after treatment. b Comparison between mutated, wild-type, and control groups as per NO levels before and after treatment 
comparing the median expression levels of DNMT3a gene between AML group and control group, it was noticeable that AML group exhibited significantly higher expression levels in comparison to control group either before or after the administration of chemotherapy with $P$ values $<0.001$ for each. Moreover, there is a statistically discernible decline of DNMT3a expressions after chemotherapy when compared to before chemotherapy with a $P$ value of 0.001 (Table 2). Figure 2 exhibits differential DNMT3a expression in patients and controls.

As the gene was universally expressed in all the study participants even the controls, Sanger sequencing of DNMT3a gene was performed so as to identify cases having a mutation in the hotspot region (R882) of DNMT3a gene (mutant) from those harboring no mutation (wild-type). There were 33 patients $(73 \%)$ having a wild-type gene and 12 patients (27\%) having mutant gene. In the 12 cases having a mutation, arginine residue was substituted for histidine in the majority of them (7/ 12), for cysteine in 3 cases and proline in 2 cases.

Patients were segregated in accordance with the magnitude of expression of the gene. A receiver operating characteristics (ROC) curve was plotted for that purpose to define a cut-off value in relation to the mutational status as seen in Table 3. The cut-off point identified was 46.5 , with a sensitivity of $75 \%$ and a specificity of $60.6 \%$ with $40.9 \%$ PPV and $87 \%$ NPV. This subdivided AML group into two further subgroups: low expressors with DNMT3a expression below 46.5 and high expressors with expression at or above that figure. Low expressors included 22 patients (48.9\%) and high expressors consisted of 23 patients (51.1\%).

A comparison between both sub-groups was held regarding the different demographic, clinical data as well as clinical outcome as demonstrable in Table 4. There was no statistically significant difference between both sub-groups in regard to age or sex with $P$ values of 0.46 and 0.87 , respectively. Both sub-groups exhibited similarity in regard to their total leucocytic count (TLC), hemoglobin, platelets, peripheral blood, and bone marrow blast percentages with $P$ values $>0.05$. There was no obvious predilection neither to any FAB subtype nor to a specific cytogenetic risk group.

Table 5 shows DNMT3a mRNA transcript levels as well as nitric oxide values in low and high expressors before and after treatment. Low expressors showed a median mRNA transcript levels of 27.8 before treatment versus 61.2 for high expressors. After treatment, these figures fell to 10.2 and 43.6 in low and high expressors, respectively.

Furthermore, both sub-groups had similar clinical outcomes concerning the response to chemotherapy and the overall survival with $P$ values of 0.92 and 0.49 , respectively. To illustrate, both sub-groups were similar in terms of the overall response with $40.9 \%$ response rate in low expressors versus $34.8 \%$ in high ones. Death was encountered in $40.9 \%$ in low expressors as compared to $47.8 \%$ in high expressors, whilst $18.2 \%$ of cases were refractory versus $17.4 \%$ in low and high expressors, respectively. This highlights that both sub-groups showed similar clinical outcomes despite the minor differences in favor of a better outcome in low expressors. As for the implication of DNMT3a gene expression on survival, it was demonstrable that both sub-groups had comparable median survival; being 37.5 and 37 days for low and high expressors, respectively. Figure 3 represents a Kaplan Meier curve of overall survival in relation to DNMT3a expression.

Table 2 Comparison between the two studied groups according to DNMT3A expression and NO level before and after treatment

\begin{tabular}{|c|c|c|c|}
\hline & \multicolumn{2}{|l|}{ Cases } & \multirow{2}{*}{$\begin{array}{l}\text { Control } \\
(\boldsymbol{n}=10)\end{array}$} \\
\hline & $\begin{array}{l}\text { Before } \\
(\boldsymbol{n}=45)\end{array}$ & $\begin{array}{l}\text { After } \\
(\boldsymbol{n}=26)\end{array}$ & \\
\hline \multicolumn{4}{|l|}{ DNMT3A expression } \\
\hline Min.-Max. & $18.60-83.60$ & $2.96-71.20$ & $0.54-1.72$ \\
\hline Mean \pm SD & $46.64 \pm 19.90$ & $24.88 \pm 21.39$ & $0.94 \pm 0.36$ \\
\hline Median & 46.50 & 17.05 & 0.98 \\
\hline Significance between groups & \multicolumn{2}{|c|}{$\mathrm{p}_{1}<0.001^{*}, \mathrm{p}_{2}<0.001^{*}, \mathrm{p}_{3}<0.001^{*}$} & \\
\hline \multicolumn{4}{|l|}{ NO level } \\
\hline Min.-Max. & $0.53-60.90$ & $0.0-27.50$ & $0.0-22.11$ \\
\hline Mean \pm SD & $16.06 \pm 13.90$ & $8.81 \pm 7.43$ & $7.83 \pm 7.35$ \\
\hline Median & 12.0 & 6.20 & 5.80 \\
\hline Significance between groups & \multicolumn{2}{|c|}{$p_{1}=0.008^{*}, p_{2}=0.035^{*}, p_{3}=0.538$} & \\
\hline
\end{tabular}

$\mathrm{p}_{1}: P$ value for Wilcoxon signed-ranks test for comparing between before and after

$\mathrm{p}_{2}: P$ value for Mann-Whitney test for comparing between before and control

$\mathrm{p}_{3}$ : $P$ value for Mann-Whitney test for comparing between after and control 


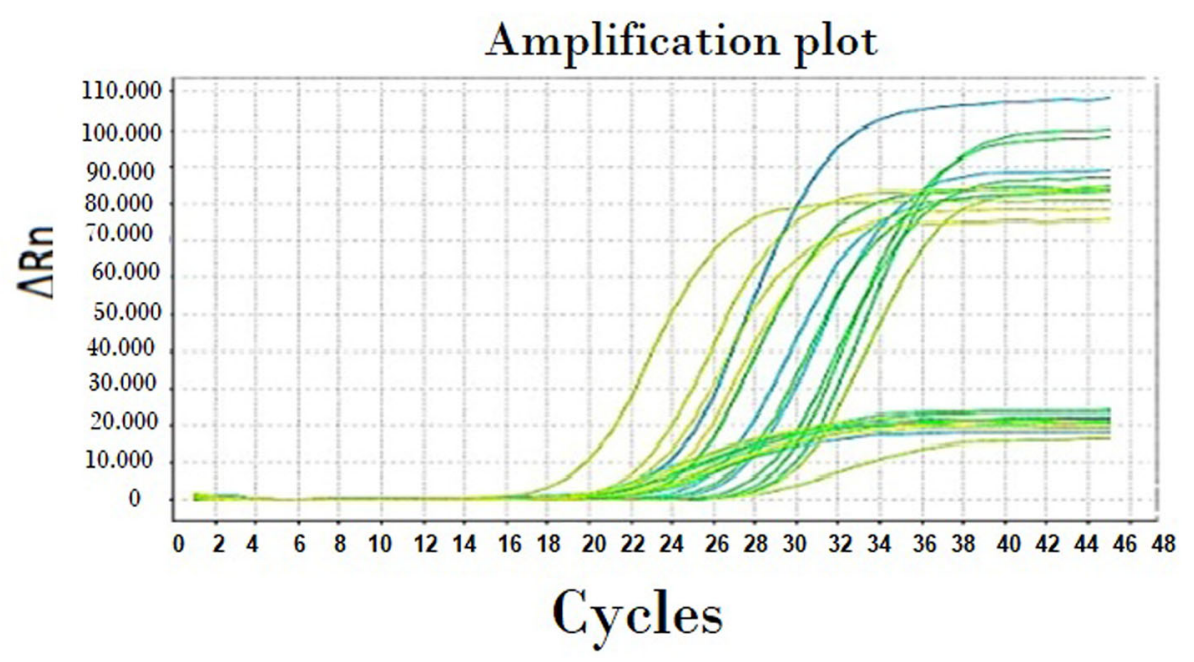

Fig. 2 DNMT3A mRNA expressions in patient and control groups by RQ-PCR

\section{DNMT3a mutational status}

Upon comparing the patient cohort having DNMT3a mutation to those having no mutation in terms of their age, sex, different full blood count parameters as TLC, hemoglobin and platelets, peripheral blood as well as bone marrow blast percentages, there were no prominent differences with $P$ values of $0.85,0.34,0.45,0.98$, $0.30,0.73$, and 0.57 , respectively. Also, there was no association to any FAB subtype or cytogenetic risk group.

There is no obvious difference between mutated and un-mutated cases with respect to DNMT3a gene expressions or NO levels either before or after treatments as demonstrable in Table 6. Although pre-chemotherapy DNMT3a gene expression is higher in mutated cases, being 54 compared to un-mutated cases, being 39, this did not reach a statistical significance with a $P$ value of 0.063 . However, post-chemotherapy figures are nearly the same for both un-mutated and mutated cases, being 14.05 and 18.25 , respectively with a $P$ value of 0.48 .

DNMT3a mutational status has not influenced therapy outcomes. Patients with wild-type gene had comparable chemotherapy response to those with the mutant gene. Despite slightly longer median survival observed among un-mutated group, being 45 days in comparison to 25 days for the mutated group, this did not have any statistical impact with a $P$ value of 0.14 . Both groups enjoy similar overall survival with $P$ value $>0.05$ as wellillustrated in Fig. 4.

\section{Nitric oxide}

NO level in the serum of AML pre-chemotherapy group ranged from $0.5 \mathrm{Umol} / 1$ to $60.9 \mathrm{Umol} / 1$ with a median $12 \mathrm{Umol} / \mathrm{l}$ and IQR $16.77 \mathrm{Umol} / \mathrm{l}$ in comparison to control group, where the range was from $0 \mathrm{Umol} / \mathrm{l}$ to 22.11 Umol/l. Reassessment was performed for AML group after induction chemotherapy on day 28 to demonstrate a median level of $6.2 \mathrm{Umol} / \mathrm{l}$ ranging from $0 \mathrm{Umol} / \mathrm{l}$ to $27.5 \mathrm{Umol} / \mathrm{l}$ with IQR of $8.8 \mathrm{Umol} / \mathrm{l}$.

This demonstrates significantly higher $\mathrm{NO}$ values in patients' cohort in relation to control cohort before receiving chemotherapy with a $P$ value of 0.035 . However; after receiving chemotherapy, patients had a comparable median serum nitrite level to that of controls with a $P$ value of 0.54. Interestingly, cases had a significantly lower median NO level after receiving chemotherapy when compared to themselves pre-chemotherapy with a $P$ value of 0.01 .

Another ROC curve was plotted for nitric oxide versus DNMT3a mutation. The cut-off point was $\leq 13 \mathrm{Umol} / \mathrm{l}$ with a sensitivity of $75 \%$ and a specificity of $51.52 \%$ with

Table 3 Agreement (sensitivity, specificity) for different parameters to diagnose mutated cases cut-off point as described in the ROC curve

\begin{tabular}{|c|c|c|c|c|c|c|c|c|}
\hline & AUC & $P$ & $95 \%$ C.I & Cut-off & Sensitivity & Specificity & PPV & NPV \\
\hline DNMT3A expression & 0.683 & 0.063 & $0.50-0.87$ & $>46.5$ & 75.0 & 60.61 & 40.9 & 87.0 \\
\hline NO level & 0.616 & 0.238 & $0.43-0.80$ & $\leq 13.4$ & 75.0 & 51.52 & 36.0 & 85.0 \\
\hline
\end{tabular}


Table 4 Comparison between low and high DNMT3a gene expressors with respect to their demographics as well as clinical data

\begin{tabular}{|c|c|c|c|c|c|c|}
\hline & \multicolumn{4}{|c|}{ Level of expression } & \multirow[t]{3}{*}{ Test of sig. } & \multirow[t]{3}{*}{$p$} \\
\hline & \multicolumn{2}{|c|}{$\begin{array}{l}\text { Low expression } \\
(\boldsymbol{n}=22)\end{array}$} & \multicolumn{2}{|c|}{$\begin{array}{l}\text { High expression } \\
(\boldsymbol{n}=23)\end{array}$} & & \\
\hline & No. & $\%$ & No. & $\%$ & & \\
\hline \multicolumn{7}{|l|}{ Sex } \\
\hline Male & 12 & 54.5 & 12 & 52.2 & \multirow[t]{2}{*}{$x^{2}=0.025$} & \multirow[t]{2}{*}{0.873} \\
\hline Female & 10 & 45.5 & 11 & 47.8 & & \\
\hline \multicolumn{7}{|l|}{ Age (years) } \\
\hline Min.-Max. & \multicolumn{2}{|l|}{$20.0-72.0$} & \multicolumn{2}{|l|}{$20.0-78.0$} & \multirow[t]{3}{*}{$t=0.754$} & \multirow[t]{3}{*}{0.455} \\
\hline Mean \pm SD & \multicolumn{2}{|l|}{$44.05 \pm 14.85$} & \multicolumn{2}{|c|}{$47.70 \pm 17.47$} & & \\
\hline Median & \multicolumn{2}{|l|}{42.50} & \multicolumn{2}{|l|}{53.0} & & \\
\hline \multicolumn{7}{|l|}{ Co-Morbidities } \\
\hline None & 16 & 72.7 & 14 & 60.9 & \multirow[t]{3}{*}{$x^{2}=0.927$} & \multirow[t]{3}{*}{${ }^{M} C_{p}=0.743$} \\
\hline Single & 4 & 18.2 & 5 & 21.7 & & \\
\hline Multiple & 2 & 9.1 & 4 & 17.4 & & \\
\hline \multicolumn{7}{|l|}{ Cytogenetic } \\
\hline Poor risk & 4 & 57.1 & 3 & 42.9 & \multirow[t]{3}{*}{$x^{2}=3.012$} & \multirow[t]{3}{*}{${ }^{M} C_{p}=0.248$} \\
\hline Intermediate risk & 15 & 60 & 10 & 40 & & \\
\hline Good risk & 4 & 44.4 & 9 & 55.6 & & \\
\hline \multicolumn{7}{|l|}{ Total leucocyte count } \\
\hline Min.-Max. & $1.0-152.0$ & & $1.0-236.0$ & & $U=217.50$ & 0.419 \\
\hline Mean \pm SD & $27.59 \pm 37.82$ & & $45.48 \pm 76$ & & & \\
\hline Median & 11.0 & & 6.0 & & & \\
\hline Hemoglobin & & & & & & \\
\hline Min.-Max. & $4.0-12.0$ & & $5.0-12.0$ & & $t=0.771$ & 0.445 \\
\hline Mean \pm SD & $7.27 \pm 1.98$ & & $7.74 \pm 2.07$ & & & \\
\hline Median & 8.0 & & 8.0 & & & \\
\hline Platelets & & & & & & \\
\hline Min.-Max & $4.0-345.0$ & & $4.0-248.0$ & & $U=242.50$ & 0.812 \\
\hline Mean \pm SD & $68.18 \pm 80.60$ & & $60.91 \pm 64$ & & & \\
\hline Median & 42.0 & & 38.0 & & & \\
\hline Peripheral blast & & & & & & \\
\hline Min.-Max. & $10.0-82.0$ & & $0.0-87.0$ & & $U=249.0$ & 0.928 \\
\hline Mean \pm SD & $37.09 \pm 24.16$ & & $36.35 \pm 24$ & & & \\
\hline Median & 34.0 & & 30.0 & & & \\
\hline Bone marrow blast & & & & & & \\
\hline Min.-Max. & $40.0-92.0$ & & $30.0-99.0$ & & $t=1.042$ & 0.303 \\
\hline Mean \pm SD & $72.32 \pm 16.59$ & & $66.61 \pm 19$ & & & \\
\hline Median & 75.0 & & 67.0 & & & \\
\hline NO level & $2.79-46.9$ & & $3.2-60.9$ & & 0.931 & 0.352 \\
\hline & $14.17(16.30)$ & & $12.20(12.2$ & & & \\
\hline Remission Status & & & & & & \\
\hline Responders (CR and PR) & 9 & 40.9 & 8 & 34.8 & $x^{2}=0.331$ & ${ }^{M C_{p}}=0.924$ \\
\hline Refractory & 4 & 18.2 & 4 & 17.4 & & \\
\hline Died & 9 & 40.9 & 11 & 47.8 & & \\
\hline
\end{tabular}


Table 4 Comparison between low and high DNMT3a gene expressors with respect to their demographics as well as clinical data (Continued)

\begin{tabular}{|c|c|c|c|c|c|c|}
\hline & \multicolumn{4}{|c|}{ Level of expression } & \multirow[t]{3}{*}{ Test of sig. } & \multirow[t]{3}{*}{$p$} \\
\hline & \multicolumn{2}{|c|}{$\begin{array}{l}\text { Low expression } \\
(\boldsymbol{n}=22)\end{array}$} & \multicolumn{2}{|c|}{$\begin{array}{l}\text { High expression } \\
(\boldsymbol{n}=23)\end{array}$} & & \\
\hline & No. & $\%$ & No. & $\%$ & & \\
\hline Alive & 7 & 31.8 & 7 & 30.4 & $x^{2}=0.010$ & 0.920 \\
\hline Died & 15 & 68.2 & 16 & 69.6 & & \\
\hline \multicolumn{7}{|c|}{ Duration of survival } \\
\hline Min.-Max. & \multicolumn{2}{|c|}{$10.0-90.0$} & \multicolumn{2}{|c|}{$10.0-90.0$} & $U=223.0$ & 0.489 \\
\hline Mean \pm SD & \multicolumn{2}{|c|}{$49.18 \pm 31.53$} & \multicolumn{2}{|c|}{$45.0 \pm 32.02$} & & \\
\hline Median & \multicolumn{2}{|c|}{37.50} & \multicolumn{2}{|l|}{37.0} & & \\
\hline
\end{tabular}

$\mathrm{X}^{2}, \mathrm{p}: \mathrm{X}^{2}$ and $P$ values for chi-square test

${ }_{\mathrm{MC}} \mathrm{p}: P$ value for Monte Carlo for chi-square test

$U, p: U$ and $p$ values for Mann-Whitney test

$\mathrm{t}, \mathrm{p}$ : $\mathrm{t}$ and $\mathrm{p}$ values for Student $t$ test

a PPV of $36 \%$ and an NPV value of $85 \%$. Table 5 compares median serum nitrite levels in low and high DNMT3a expressor sub-groups. High expressors had higher serum nitrite values in relation to low expressors either before or after therapy. High expressors displayed a median serum nitrite of $13.4 \mathrm{Umol} / \mathrm{l}$ and $7.5 \mathrm{Umol} / \mathrm{l}$ before and after treatment, whereas low expressors had a median of $9.55 \mathrm{Umol} / \mathrm{l}$ and $6.2 \mathrm{Umol} / \mathrm{l}$ before and after induction chemotherapy, respectively. Despite these discrepancies, this has not reached a statistical significance with $P$ values of 0.29 and 0.96 pre- and postchemotherapy, respectively.

\section{Discussion}

The primary aim of the present study is to assess DNMT3a gene expression and nitric oxide levels in patients with newly diagnosed de novo AML. The secondary aim was to examine their relationships with other prognostic factors of the disease, responsiveness to intensive chemotherapy as well as patients' survival.

Table 5 Comparison between levels of DNMT3A gene expression and NO level before and after treatment

\begin{tabular}{|c|c|c|c|c|c|}
\hline & & \multicolumn{2}{|c|}{ Level of expression } & \multirow[t]{2}{*}{$U$} & \multirow[t]{2}{*}{$P$} \\
\hline & & Low expression & High expression & & \\
\hline \multirow[t]{8}{*}{ DNMT3A expression } & Before & $(n=22)$ & $(n=23)$ & & \\
\hline & Min.-Max. & $18.60-42.30$ & $46.50-83.60$ & $0.000^{*}$ & $<0.001^{*}$ \\
\hline & Mean \pm SD & $29.26 \pm 8.26$ & $63.27 \pm 11.65$ & & \\
\hline & Median & 27.80 & 61.20 & & \\
\hline & After & $(n=13)$ & $(n=13)$ & & \\
\hline & Min.-Max. & $2.96-23.40$ & $5.69-71.20$ & $17.00^{*}$ & $0.001^{*}$ \\
\hline & Mean \pm SD & $10.58 \pm 6.68$ & $39.18 \pm 21.57$ & & \\
\hline & Median & 10.20 & 43.60 & & \\
\hline \multirow[t]{8}{*}{ NO Level } & Before & $(n=22)$ & $(n=23)$ & & \\
\hline & Min.-Max. & $0.53-46.90$ & $3.20-60.90$ & 207.00 & 0.296 \\
\hline & Mean $\pm S D$ & $14.14 \pm 12.44$ & $17.90 \pm 15.21$ & & \\
\hline & Median & 9.55 & 13.40 & & \\
\hline & After & $(n=13)$ & $(n=13)$ & & \\
\hline & Min.-Max. & $0.0-26.60$ & $0.0-27.50$ & 83.50 & 0.959 \\
\hline & Mean \pm SD & $8.47 \pm 6.81$ & $9.15 \pm 8.26$ & & \\
\hline & Median & 6.20 & 7.50 & & \\
\hline
\end{tabular}




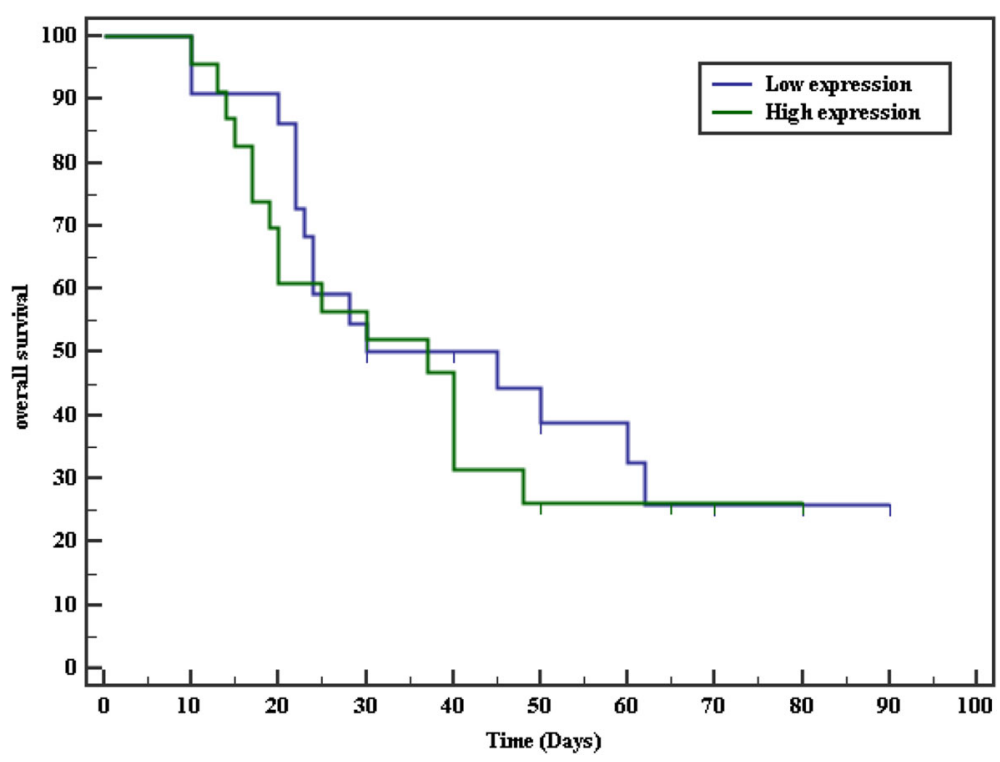

Fig. 3 Kaplan-Meier curve of the overall survival in relation to the level of gene expression

The present study included 45 adult newly diagnosed cases of de novo AML and 10 healthy control subjects matched as for age and sex.

The Cancer Genome Atlas has determined that $44 \%$ of patients with AML show recurrent mutations in the genes that control the methylation of genomic DNA. Moreover, significant changes in DNA methylation had been identified across AML samples at the abundance of CpG loci. These results indicate that DNA methylation could be important for leukemogenesis [17]. And hence, the assessment of DNMT3a expression using RQ-PCR was done in both AML group and control group. It was noticeable that all the participants either patients or controls were expressing DNMT3a. However; DNMT3a

Table 6 Comparison of DNMT3A expression and NO level before and after treatment in relation to DNMT3A mutational status

\begin{tabular}{|c|c|c|c|c|c|}
\hline & & \multicolumn{2}{|c|}{ DNMT3A mutation } & \multirow[t]{2}{*}{$U$} & \multirow[t]{2}{*}{$P$} \\
\hline & & Mutated & Wild-type & & \\
\hline \multirow[t]{8}{*}{ DNMT3A expression } & Before & $(n=12)$ & $(n=33)$ & & \\
\hline & Min.-Max. & $19.70-83.60$ & $18.60-79.40$ & 125.50 & 0.063 \\
\hline & Mean \pm SD & $56.43 \pm 21.15$ & $43.09 \pm 18.49$ & & \\
\hline & Median & 54.85 & 39.60 & & \\
\hline & After & $(n=6)$ & $(n=20)$ & & \\
\hline & Min.-Max. & $2.96-62.10$ & $3.02-71.20$ & 48.50 & 0.484 \\
\hline & Mean \pm SD & $20.16 \pm 21.70$ & $26.29 \pm 21.65$ & & \\
\hline & Median & 14.05 & 18.25 & & \\
\hline \multirow[t]{8}{*}{ NO level } & Before & $(n=12)$ & $(n=33)$ & & \\
\hline & Min.-Max. & $0.53-30.20$ & $2.70-60.90$ & 152.0 & 0.238 \\
\hline & Mean \pm SD & $11.49 \pm 9.12$ & $17.72 \pm 15.04$ & & \\
\hline & Median & 10.12 & 14.70 & & \\
\hline & After & $(n=6)$ & $(n=20)$ & & \\
\hline & Min.-Max. & $0.0-13.10$ & $0.0-27.50$ & 50.0 & 0.543 \\
\hline & Mean \pm SD & $6.25 \pm 4.49$ & $9.58 \pm 8.03$ & & \\
\hline & Median & 6.10 & 6.46 & & \\
\hline
\end{tabular}




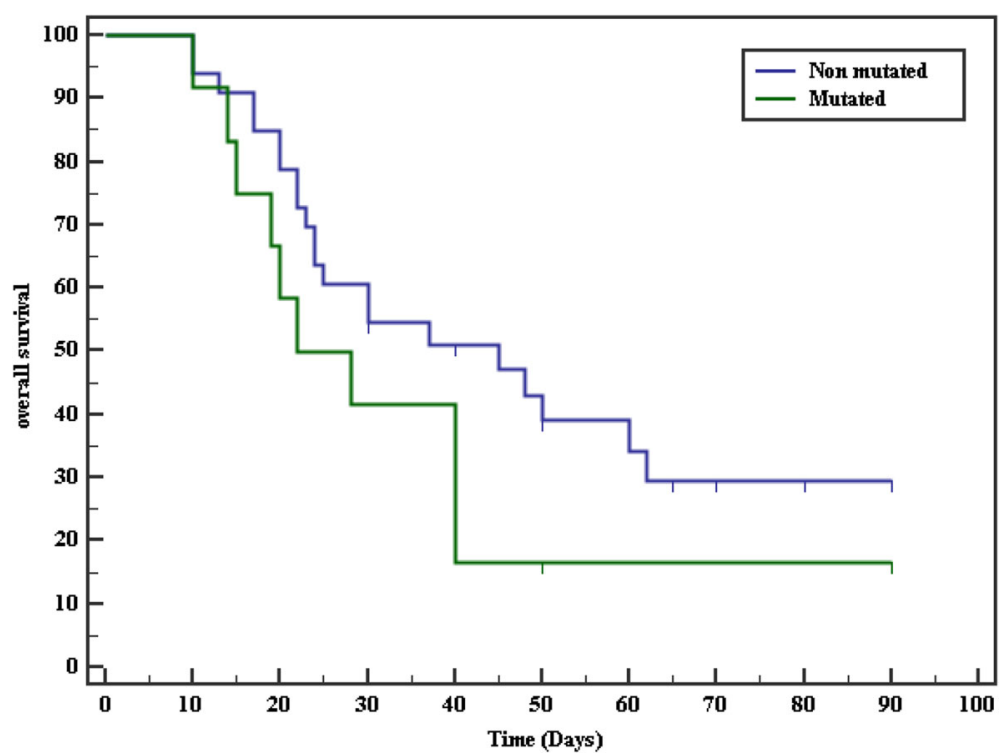

Fig. 4 Kaplan-Meier survival curve for overall survival in relation to DNMT3A mutation

expression in the control group was far below that of patients either before or after the institution of chemotherapy. In addition, patients after receiving treatment exhibited a statistically remarkable lowering of their readings in comparison to the same cohort before treatment.

This is in congruence with the study performed by Lin and colleagues [17] examining DNMT3a expressions among cases of AML and controls, also it assessed the expression of different splicing variants in AML. It was found that all patients expressed DNMT3a in that study as in ours, but they proved that DNMT3a variant 2 was significantly upregulated in comparison to DNMT3a variant 1 and that both variants were the main ones expressed in AML patients in comparison to other variants such as DNMT3a variant 3 or variant 4 [17]. In our study, the assessment of variable expression of DNMT3a splicing variants was not performed so as to be compared with that observation that needs further verification.

AML group was divided into high and low expressors of DNMT3a as per their mutational status with the comparison of both groups in terms of patients and disease characteristics. We failed to prove an association between DNMT3a expression status and any of the patients or disease aggressiveness features. But, high expressors exhibited slightly higher mortality during induction at $47.8 \%$ versus $40.9 \%$ for low expressors, slightly lower remission rates at $34.8 \%$ versus $40.9 \%$, and almost comparable refractoriness rate at $17.4 \%$ versus $18.2 \%$. Nonetheless, all of these were subtle differences that did not reach statistical significance with $P$ values $>0.05$. This might indicate that high expressors may be subjected to worse outcome in relation to low expressors and that a more ample sample size may be needed to prove or refute this hypothesis. Another point that can be raised is whether the use of hypomethylating agents may alter the outcome in such patients if used in conjunction with the standard induction chemotherapy.

Mutational analysis of DNMT3a gene has been performed. It was found that 12 out of 45 (i.e., $26 \%$ of cases) harbored DNMT3a R882 mutation. This is almost comparable to the incidence of mutations in a study conducted by Ley et al.in 2010. In that study, mutations were identified in 62/281 (i.e., 22\%) [18]. But in our study, we evaluated only the mutation that affects the gene hotspot region R882, whereas Ley and coworkers assessed a wide range of mutations affecting different regions of the gene. They retrieved R882 mutation in only 37 patients, i.e., $13 \%$ of all cases enrolled. This is far below the incidence of that kind of mutation in our study which was double that figure. By sharp contrast to this, in a Brazilian study conducted by Pezzi et al, in 2012, it was found that incidence of DNMT3a mutations in AML patients was much lower than the incidence reported in our dataset as well as that noted by Ley et al. Of 82 AML samples collected, only 6 samples exhibited DNMT3a mutations with R882H identifiable in only 3 patients. Other mutations affecting other parts rather than the methyltransferase domain were also identifiable [19]. Another Taiwanese study by Hou et al. 2012 corroborated findings of the Brazilian study with a lower incidence of DNMT3a mutations in $14 \%$ of 500 patients recruited [5]. The wide range of variability among AML 
patients' population concerning the prevalence of DNMT3a mutations might be largely explained by ethno-geographic variations.

Mutated and un-mutated cases were compared in terms of patients and disease features. It was noticeable that both groups were comparable except for a trend towards higher DNMT3a expression in mutant cases when compared to those having wild-type DNMT3a gene with a tendency towards statistical significance with a $P$ value of 0.063 . This is ascribed to the method used to define patients into high and low expressors based on mutational status. There was no discernible disparity among mutated and un-mutated cases in terms of response or survival data, though mutated cases had a trend towards shortened survival when compared to un-mutated cases ( $\mathrm{HR}=1.707$ with $95 \% \mathrm{CI}=0.7-4)$. Tie et al. 2014 contradicts some of these findings in our study. In this meta-analysis, a total number of 12 studies, 5 American, 4 European and 3 Asian had been enrolled focusing on DNMT3a mutations in AML patients to display a total number of 1161 patients having mutations out of 6377 patients enrolled (i.e., 18\%). It was found that patients with mutated DNMT3a had higher TLC and bone marrow blast percentages in comparison to those with the wild-type gene. In addition, they displayed lower overall as well as relapse-free survival in comparison to their un-mutated counterparts [7]. This may be partly attributed to the small sample size in our cohort. Also, only R882 mutations were identified in our study whereas, in Tie et al, DNMT3a mutations in any region of the gene were reported. Another study by Hou et al. 2012 showed that DNMT3a mutant cases exhibited higher TLC and platelets along with a tendency to cluster among cases of CN-AML (22.9\%) in comparison to the overall prevalence in all risk categories (14\%) [5].

Finally, serum nitrite has been assessed in patients before and after chemotherapy as well as in controls as an alternative to direct measurement of nitric oxide. It was found that patients before induction treatment showed higher serum nitrite levels when compared to themselves after treatment as well as to their controls with a $P$ value of 0.008 and 0.035 , respectively. Whereas serum nitrite values were comparable among patients post-chemotherapy and controls with $P$ value of 0.538 . These findings were concordant with those found by Olaniyi et al. where serum nitrate and nitrite levels were assessed in 25 patients with acute leukemia who were segregated into 14 cases of ALL and 11 cases of AML. Serum nitrite levels were compared with their values in healthy control subjects. That study culminated into the conclusion that acute leukemia patients had significantly higher oxidative/nitrosative stress that results in more nitric oxide production than their healthy control counterparts [20]. Another Indian study conducted by Sangwan et al. on 25 chronic myeloid leukemia patients showed that patients had significantly higher nitrite levels relative to their controls as well as to themselves after the introduction of imatinib mesylate for six weeks at a dose of $400 \mathrm{mg}$ twice daily [21].

Nowadays, there is an increasingly recognized dichotomous nature of $\mathrm{NO}$ in cancers. NO molecule has an unpaired single electron and so can donate it to act as an oxidant or accept an electron behaving like an antioxidant which might explain the discrepancy in its actions [22]. It may act as an oncogenic molecule promoting cellular malignant transformation, angiogenesis, tumor progression as well as spread and metastasis, but some studies emphasize its tumoricidal properties which make this area quite confusing with some trials working to develop medications to block the actions of $\mathrm{NO}$ to halt tumorous progression and others working to develop NO donors so as to serve the same purpose [19]. The final activity of NO in oncology is dependent on its working microenvironment, including the type of cell exposed to the compound, the redox state of the reaction, as well as the final intracellular concentration and the duration of intracellular exposure to NO [23]. At low levels, NO can lead to tumor formation. The mechanisms of action that lead to the proneoplastic activity of $\mathrm{NO}$ are numerous but include cell proliferation by the activation of oncogenes, stimulation of angiogenesis, and apoptosis inhibition by S-nitrosylationinactivation of caspases [24]. The role of $\mathrm{NO}$ as an antioncogenic agent has also been well established to a comparable degree as its potent anticancer properties in other reports. Thus, the dual role of NO is well established and documented in the medical literature. Thus, it continues to be of crucial importance to investigate the system under study to evaluate the contribution of NO to the environment in which it is being released. In 2008, David Wink's group put much of this controversy to rest by reporting a specific concentration threshold where the bipartisan role of $\mathrm{NO}$ occurred. At high concentrations ( $>200 \mathrm{nM}$ ), NO had anticancer properties; whereas, below this threshold, cell survival and a pro-neoplastic function of NO was observed [24].

These data shed the light on different nitric oxide synthase isoforms and how they differ in terms of their location, amount, context, and duration of $\mathrm{NO}$ production by each. Of them, nitric oxide synthase isoenzyme 2 (NOS2) or the inducible nitric oxide synthase(iNOS) is the most important and its activity is associated with the release of larger micromolar amounts for extended periods that may last for hours or even days in comparison to the constitutively expressed isoforms nitric oxide synthase isoenzyme 1 (NOS1) (neuronal) and nitric oxide synthase isoenzyme 3 (NOS3) (endothelial) that produce smaller bursts which are nanomolar for shorter durations of minutes to hours. This NOS2 may give us a great insight about the relationship between chronic inflammation and cancers as it is abundantly expressed in macrophages and monocytes and is transcriptionally induced by 
various pro-inflammatory stimuli as tumor necrosis factor-alpha, interleukin 1, and interferon-gamma [25].

In a study by Cianchi et al. 2003, the oncogenic role of NO was asserted by their findings that there was significantly more colorectal cancer specimens' expression of iNOS as compared to normal mucosa. Also, there was a significant positive correlation between iNOS expression from one side and vascular endothelial growth factor (VEGF) expression and microvessel density from the other side. Metastatic tumors expressed more iNOS than non-metastatic ones [26].

\section{Conclusion}

In conclusion; DNMT3a gene expression is increased among AML population in comparison to normal healthy control. Moreover, there is higher nitrosative stress in AML patients than controls; however, no association between DNMT3a expression and nitrosative status could be delineated in our study. This may point out to the need to assess the influence of DNMT3a gene expression on the methylcytosine content of tumor samples with the subsequent implementation of hypomethylating agents as a line of therapy in cases exhibiting excessive hypermethylation. Furthermore, the utilization of medications to halt the NO action may be experimented to reduce AML progression.

\begin{abstract}
Abbreviations
ACTB: Beta-actin reference gene; AML: Acute myeloid leukemia; APL: Acute promyelocytic leukemia; ATRA: All-trans retinoic acid; CBF: Core-binding factor; CDNA: Complementary DNA; CN-AML: Cytogenetically normal acute myeloid leukemia; CpG: 5'Cytosine-phosphate-guanine3'; CR: Complete remission; CRP: C-reactive protein; CT: Cycle threshold; DNA: Deoxyribonucleic acid; DNMT1: DNA methyltransferase 1; DNMT3a: DNA methyltransferase 3a; DNMT3b: DNA methyltransferase 3b; DNMT3L: DNA methyltransferase 3 L; DNMTs: DNA methyltransferases; FAB: French-American-British; HiDAC: High-dose cytarabine; iNOS: Inducible nitric oxide synthase; IV: Intravenous; mmoll: Millimole/liter; mRNA: messenger ribonucleic acid; MSD: Matched sibling donor; NCCN: National Comprehensive Cancer Network; ng/ul: Nanogram per microliter; nm: Nanometer; NO: Nitric oxide radical; NO2: Nitrogen dioxide radical; NOS1: Nitric oxide synthase isoenzyme 1; NOS2: Nitric oxide synthase isoenzyme 2; NOS3: Nitric oxide synthase isoenzyme 3; ONOO

-: Peroxynitrite; PCR: polymerase chain reaction; PR: Partial remission; R882: Arginine 882; RNA: Ribonucleic acid; RNS: Reactive nitrogen species; ROC: Receiver operating characteristics; rpm: Round per minute; RQPCR: Real-time polymerase chain reaction; TLC: Total leucocytic count; uL: Microliter; $\mu \mathrm{M}$ : Micromole; $\mu \mathrm{mol} / \mathrm{l}:$ Micromole/liter
\end{abstract}

\section{Acknowledgements}

Not applicable.

\section{Ethical approval and consent to participate}

This study was approved by the ethics committee of Ain Shams University with the reference number/approval number of 616.99419 22, and written consent was given by the study participant.

It was conducted according to the declaration of Helsinki.

Ain Shams University

Faculty Of Medicine

Ethical Committee Of Scientific Research

Informed consent form for patients who are invited to participate in the research
Research title Prognostic Significance of DNMT3a Gene Expression and Reactive Nitrogen Species in Newly Diagnosed Egyptian De-novo Adult Acute Myeloid Leukemia Patients Introduction and Aim of work

Acute myeloid leukemia is a disease that shows remarkable heterogeneity in biological, clinical and molecular characteristics. DNMT3a gene is involved in the process of denovo DNA methylation which is a major epigenetic modifying mechanism for gene expression. There is accumulating evidence in the literature about the critical role of this mechanism in the process of carcinogenesis. Also, the dichotomous nature of nitric oxide action promoting or repressing cancers is increasingly realized. There is a host of research work delineating the frequency of DNMT3a mutation in AML, but little is known about its level of expression or a probable relationship with nitrosative stress.

The study aims at the assessment DNMT3a gene expression as well as nitric oxide levels in newly diagnosed adult patients with denovo AML. Moreover, it aims at relating these two variables to other disease features and prognostic indicators as well as treatment outcomes.

Place of work

Ain Shams University, Clinical Hematology and Oncology Unit, Department of Internal medicine.

Number and Selection of Participants

The study included 45 adult denovo AML patients and 10 healthy control subjects.

Inclusion Criteria

- Adult patients of 18 years old or more.

- Newly diagnosed AML patients by the standard diagnostic criteria.

- Patients who were deemed fit for chemotherapy.

Exclusion criteria

- Secondary acute leukemia.

- Biphenotypic or bileaneage Acute Leukemia.

- Relapsed Acute Leukemia.

- Patients who were considered unfit to intensive chemotherapy of curative intent.

Plan of work:

All cases enrolled in the study will be routinely subjected to

1 -Full medical history.

2-Thorough clinical examination.

3-Measurement of DNMT3a gene expression by RT-PCR

4-Assessment of DNMT3A mutations by Sanger sequencing

5-Detection of nitric oxide (NO) by colorimetric methods

Benefits expected from the study

1-Benefits to the participants:

To find out a relationship between DNMT3a gene expression and RNS status in AML and disease aggressiveness. This can hold the gate open to future molecular as well as targeted therapies

Risks and complications:

This research will not expose you to any further risks or complications rather than the standard risks incurred by AML induction and consolidation chemotherapy protocols in Clinical Hematology and Oncology Unit of Ain Shams University Hospital.

The risk of blood sampling:

A single blood sample $5 \mathrm{ml}$ will be obtained by trained professional nurse from antecubital fossa of the upper arm using sterile, disposable equipment. The risks of bleeding, bruising, or infection are small, and similar to having blood drawn at your doctor's office.

Some subjects report a feeling of dizziness or fainting upon withdrawing the blood sample. However, the volume of blood (5 milliliters) is small, and will be replaced quickly by your body.

Reimbursements in cases of risks and complications:

Should you get physically injured as a result of research related procedures, Doctor Dina Abdou Mansour will provide the first aid medical treatment. Confidentiality:

All the data and information provided by you to the research will be private and will not be disclosed to anyone but the main researcher and supervisors of the research.

Certificate of consent:

I have read the former information, or it has been read to me. I have had the opportunity to ask questions about it and any questions that I had asked have been answered to my satisfaction. I consent voluntarily to participate in this research and I know that I have the choice to participate or not. Even if I 
do not participate in that research, I will be offered the standard medical care given routinely in Ain Shams Clinical Hematology and Oncology Unit. I can make up my mind at any time throughout the research and stop participation even if I agreed earlier.

- Name of participant:

- Signature of participant:

- Identity number or finger print:

- Date: / /

I have accurately read or witnessed the accurate reading of the consent to the potential participant. The individual has had the opportunity to ask questions. I confirm that the individual has given consent freely.

- Name of researcher:

- Signature of researcher:

- Date: / /

This proposal has been reviewed and approved by Ethical Committee of Scientific research, which is a committee whose task is to make sure that research participants are protected from harm.

\section{Authors' contributions}

IAA is the principal investigator who had the research point, she created the study design, contributed to the analysis of the study data. HMH contributed to the analysis of data. WAE contributed to the analysis of data and contributed to writing and revising the manuscript. MTH contributed to the laboratory work including bone marrow aspirate histological examination and immunophenotypic evaluation and performing polymerase chain reaction for DNMT3a. DAM collected the clinical as well as the laboratory data. AMS analyzed the data, drafted the manuscript, and revised it. Furthermore, she is the corresponding author. All authors have read and approved the manuscript.

\section{Funding}

This research did not receive any specific grant from funding agencies in the public, commercial, or not-for-profit sectors.

\section{Availability of data and materials}

Data and materials are available upon request.

\section{Consent for publication}

The publication of the article is approved by all the study participants. Patient Consent for Publication statement

The following information must be provided in order for this form to be processed accurately. Patients have the right to refuse to sign this consent form; refusal to sign this form will.

I hereby give my consent for images or other clinical information relating to my case to be reported in a medical publication.

I understand that my name and initials will not be published and that efforts will be made to conceal my identity, but that anonymity cannot be guaranteed.

I understand that the material may be published in a journal, Web site or other form of publication. As a result, I understand that the material may be seen by the general public.

I understand that the material may be included in medical books.

Name of the patient

Patient's date of birth

Signature of patient

\section{Competing interests}

The authors declare no competing financial interests or conflict of interest.

\section{Author details}

${ }^{1}$ Department of Internal Medicine, Clinical Hematology and Oncology Unit, Faculty of Medicine, Ain Shams University, Cairo, Egypt. 'Department of Clinical Pathology, Faculty Of Medicine, Ain Shams University, Cairo, Egypt.

Received: 29 November 2019 Accepted: 4 May 2020

Published online: 24 August 2020

\section{References}

1. Yang X, Wang J (2018) Precision therapy for acute myeloid leukemia. J Hematol Oncol., 11, 3. https://doi.org/https://doi.org/10.1186/s13045-017-0543-7.
2. Goldman SL, Hassan C, Khunte M, Soldatenko A, Jong Y, Afshinnekoo E, et al (2019) Epigenetic modifications in acute myeloid leukemia: prognosis, treatment, and heterogeneity. Front Genet.; 10: 133. https:// doi:https://doi. org/10.3389/fgene.2019.00133.

3. Subramaniam D, Thombre R, Dhar A, Anant S (2014) DNA methyltransferases: a novel target for prevention and therapy. Front Oncol., 1,4. https://doi: https://doi.org/10.3389/fonc.2014.00080.

4. Kumar D, Mehta A, Panigrahi MP, Nath S, Saikia KK (2018) DNMT3A (R882) mutation features and prognostic effect in in Coexistent with NPM1 and FLT3 mutations. Hematol Oncol Stem Cell Ther., 11, 82-89. https://doi: https://doi.org/10.1016/j.hemonc.2017.09.004.

5. Hou HA, Kuo YY, Liu CY, Chou WC, Lee MC, Chen CY, et al (2012) DNMT3A mutations in acute myeloid leukemia: stability during disease evolution and clinical implications. Blood.;119: 559-568 https:// doi: https://doi.org/10.1182/ blood-2011-07-36993.

6. Lu R, Wang P, Parton T, Zhou Y, Chrysovergis K, Rockowitz S, et al(2016) Epigenetic Perturbations by Arg882-Mutated DNMT3A Potentiate Aberrant Stem Cell Gene-Expression Program and Acute Leukemia Development. Cancer cell., 30, 92-107.https:// doi: https://doi.org/10.1016/j.ccell.2016.05.008.

7. Tie R, Zhang T, Fu H, Wang L, Wang Y, Heet Y,et al (2014) Association between DNMT3A mutations and prognosis of adults with de novo acute myeloid leukemia: a systematic review and meta-analysis. PLoS One. , 9, e93353. https://doi: https://doi.org/10.1371/journal.pone.0093353.

8. Dhawan V (2014) Reactive Oxygen and Nitrogen Species: General Considerations. In: Ganguly N, Jindal S, Biswal S, Barnes P, Pawankar R. (editors) Studies on Respiratory Disorders. Oxidative Stress in Applied Basic Research and Clinical Practice. 12th edition. New York: Humana Press. https://doi.org/10.1007/978-1-4939-0497-6_2.

9. Choudhari SK, Chaudhary M, Bagde S, Gadbail AR, Joshi V (2013) Nitric oxide and cancer: a review. World J Surg Oncol., 11,118. https://doi: https://doi. org/10.1186/1477-7819-11-118.

10. National Comprehensive Cancer Network (2016) Acute myeloid leukemia. National Comprehensive Cancer Network Clinical Practice Guidelines in Oncology-V2.2016. National Comprehensive Cancer Network [Web site]. Available at: http://www.nccn.org/professionals/physician_gls/pdf/aml.pdf. Accessed October 2016.

11. Moore JO, Dodge RK, Amrein PC, Kolitz J, Lee EJ, Powell B et al (1997) Granulocyte-colony stimulating factor (Filgrastim) Accelerates granulocyte recovery after intensive post-remission chemotherapy for acute myeloid leukemia with aziridinyl benzoquinone and mitoxantrone: cancer and leukemia group B study 9022. Blood 89 780-788

12. Sanz MA, Montesinos P, Rayo'n C, Holowiecka A, de la Serna J, Miloneet G, et al (2010) Risk-adapted treatment of acute promyelocytic leukemia based on all-trans retinoic acid and anthracycline with addition of cytarabine in consolidation therapy for high-risk patients: further improvements in treatment outcome. Blood; 115: 5137-5146. https:// doi: https://doi.org/10. 1182/blood-2010-01-266007.

13. Rahman MH, Khan MA, Islam MS, Afrose S (2012) High dose cytosine arabinoside in the consolidation of adult acute myeloid leukemia. Mymensingh Med J. 21:213-219

14. Cheson BD, Bennett JM, Kopecky KJ, Büchner T, Willman CL, Estey EH (2003) International working group for diagnosis, standardization of response criteria, treatment outcomes, and reporting standards for therapeutic trials in acute myeloid leukemia. J Clin Oncol.; 21, 4642-4649. https:// doi:https:// doi.org/10.1200/JCO.2003.04.036.

15. Page RB., Stromberg AJ (2011) Linear methods for analysis and quality control of relative expression ratios from quantitative real-time polymerase chain reaction experiments. Sci World J., 11,1383-1393. https:// doi: https:// doi.org/10.1100/tsw.2011.124.

16. Lal R, Heitzer E, Ulz P, Aubell K, Kashofer K, et al (2017) Somatic TP53 mutations characterize preleukemic stem cells in acute myeloid leukemia. Blood;129:2587-2591.https://doi: https://doi.org/10.1182/blood-2016-11751008.

17. Lin N, Fu W, Zhao C, Li B, Yan X, Li Y (2017) Biologico-clinical significance of DNMT3A variants expression in acute myeloid leukemia. Biochem Biophys Res Commun., 494, 270-277. https://doi: https://doi.org/10.1016/j.bbrc.2017. 10.041 .

18. Ley TJ, Ding L, Walter MJ, McLellan MD, Lamprecht T, Larson DE, et al (2010) DNMT3A Mutations in Acute Myeloid Leukemia. N Engl J Med.,363, 24242433. https://doi: https://doi.org/10.1056/NEJMoa1005143. 
19. Pezzi A, Moraes L, Valim V, Amorin B, Melchiades G, Oliveira F, et al (2012) DNMT3A mutations in patients with acute myeloid leukemia in south brazil. Adv Hematol., 697691. https://doi:https://doi.org/10.1155/2012/697691.

20. Olaniyi JA, Anifowose A, Akinloye O, Awosika EO, Rahamon SK, Arinola GO

(2011) Antioxidant levels of acute leukaemia patients in nigeria. Sierra Leone J Biomed Res 3:133-137

21. Sangwan L, Kumar R, Peter R, Arun P (2014) Evaluation of nitric oxide levels in chronic myeloid leukemia. Int J Innov Res Rev 2:1-5

22. Ozcan A and Ogun M (2015) Biochemistry of reactive oxygen and nitrogen species. In: basic principles and clinical significance of oxidative stress. Chapter 3. By: S. Joghi, T. Gowder (Eds.), ISBN 978-95351-2200-5, InTech: 37-56.

23. Huerta S, Chilka S, Bonavida B (2008) Nitric oxide donors: novel cancer therapeutics. Int J Oncol., 33,909-927. https://doi.org/https://doi.org/10.3892/ ijo_00000079.

24. Huerta S (2015) Nitric oxide for cancer therapy. Future Sci OA.1, ESO44. https://doi: https://doi.org/10.4155/fso.15.44

25. Vannini F., Kashfi K., Nathb N (2015) The dual role of iNOS in cancer. Redox Biol.,6, 334-43.https://doi: https://doi.org/10.1016/j.redox.2015.08.009.

26. Cianchi F, Cortesini C, Fantappiè O, Messerini L, Schiavone N, Vannacci A, et al (2003) Inducible nitric oxide synthase expression in human colorectal cancer: correlation with tumor angiogenesis. Am J Pathol., 162,793-801. https://doi:https://doi.org/10.1016/S0002-9440(10)63876-X.

\section{Publisher's Note}

Springer Nature remains neutral with regard to jurisdictional claims in published maps and institutional affiliations.

\section{Submit your manuscript to a SpringerOpen ${ }^{\circ}$ journal and benefit from:}

- Convenient online submission

- Rigorous peer review

- Open access: articles freely available online

- High visibility within the field

- Retaining the copyright to your article

Submit your next manuscript at $\boldsymbol{\nabla}$ springeropen.com 